\title{
Chitosan-clay nanocomposite as a drug delivery system of ibuprofen
}

\author{
Nanocompósitos de quitosana-argilla como sistema de liberação controlada de ibuprofeno \\ Nanocompuesto de quitosano-arcilla como sistema de liberación controlada de ibuprofeno
}

Received: 12/13/2021 | Reviewed: 12/22/2021 | Accept: 12/28/2021| Published: 01/06/2022

\author{
Albaniza Alves Tavares \\ ORCID: https://orcid.org/0000-0003-1412-4787 \\ Universidade Federal de Campina Grande, Brazil \\ E-mail: albaniza.alves@certbio.ufcg.edu.br \\ Maria Dennise Medeiros Macêdo \\ ORCID: https://orcid.org/0000-0003-2990-5447 \\ Universidade Federal de Campina Grande, Brazil \\ E-mail: dennise.macedo@certbio.ufcg.edu.br \\ Pedro Henrique Correia de Lima \\ ORCID: https://orcid.org/0000-0002-2991-1452 \\ Universidade Federal de Campina Grande, Brazil \\ E-mail: phc.lima@unesp.br \\ Rossemberg Cardoso Barbosa \\ ORCID: https://orcid.org/0000-0002-8551-5251 \\ Universidade Federal de Campina Grande, Brazil \\ E-mail: rcbvet@gmail.com \\ Wladymyr Jefferson Bacalhau Sousa \\ ORCID: https://orcid.org/0000-0002-3931-8265 \\ Universidade Federal de Campina Grande, Brazil \\ E-mail: wladymyrjb@gmail.com \\ Cristiano José de Farias Braz \\ ORCID: https://orcid.org/0000-0001-5823-633X \\ Universidade Federal de Campina Grande, Brazil \\ E-mail: cristiano.farias@gmail.com \\ Matheus Ferreira de Souza \\ ORCID: https://orcid.org/0000-0002-2191-2573 \\ Universidade Federal de Campina Grande, Brazil \\ E-mail: matheusferza@gmail.com \\ Camila Melo Gadelha Pereira Diniz \\ ORCID: https://orcid.org/0000-0003-2480-839X \\ Universidade Federal de Campina Grande, Brazil \\ E-mail: phc.lima@unesp.br \\ Marcus Vinícius Lia Fook \\ ORCID: https://orcid.org/0000-0002-8566-920X \\ Universidade Federal de Campina Grande, Brazil \\ E-mail: marcus.liafook@certbio.ufcg.edu.br \\ Suédina Maria de Lima Silva \\ ORCID: https://orcid.org/0000-0002-2073-0989 \\ Universidade Federal de Campina Grande, Brazil \\ E-mail: suedina.maria@professor.ufcg.edu.br
}

\begin{abstract}
Chitosan/montmorillonite nanocomposite films were prepared by the solvent evaporation method to immobilize the drug ibuprofen (IBU) and delay its release in a medium that simulates the environment of the gastrointestinal tract. The effects of montmorillonite, at different mass proportions (10,20, and 50\%), on the morphological and physical properties of the films were studied. The samples were characterized by X-ray diffraction (XRD), Infrared Spectroscopy (FTIR), Scanning Electron Microscopy (SEM), degree of swelling, drug encapsulation, and drug release efficiency. According to the XRD it was evidenced that the incorporation of montmorillonite to chitosan led to the formation of nanocomposites of ordered morphology. The infrared spectra confirmed the good interaction between montmorillonite and chitosan by the formation of nanocomposites. This fact, which favored the imprisonment of the IBU, reduced the diffusion coefficient in the studied systems. The micrographs comproved the formation of dense and uniform films. The controlled release profile, especially for the nanocomposite with $10 \%$ clay mass, showed a slow drug release rate. The incorporation of montmorillonite at different proportions produced different morphologies, with good encapsulation efficiency and an adequate profile for the controlled release of the drug.
\end{abstract}

Keywords: Nanocomposites; Ibuprofen; Controlled drug release. 


\begin{abstract}
Resumo
Nanocompósitos de quitosana/montmorilonita na forma de filmes foram preparados pelo método de evaporação de solvente com o intuito de imobilizar o fármaco ibuprofeno (IBU) e retardar sua liberação em um meio que simula o ambiente do trato gastrointestinal. Foram estudados os efeitos da montmorilonita em diferentes proporções de massa (10, 20 e 50\%), em função das propriedades morfológicas e físicas dos filmes. As amostras foram caracterizadas por Difração de Raios-X (DRX), Espectroscopia de Infravermelho por Transformada de Fourier, Microscopia Eletrônica de Varredura, Grau de Intumescimento, Encapsulação e Eficiência de Liberação do fármaco. De acordo com o DRX, foi constatado que a incorporação da montmorilonita à quitosana levou à formação de nanocompósitos de morfologia ordenada. Os espectros de infravermelho confirmaram a boa interação entre montmorilonita e quitosana pela formação de nanocompósitos. Esse fato, que favoreceu a prisão do IBU, reduziu o coeficiente de difusão nos sistemas estudados. As micrografias comprovaram a formação de filmes densos e uniformes. O perfil de liberação controlada, especialmente para o nanocompósito com $10 \%$ de massa de argila, apresentou uma taxa de liberação lenta do fármaco. Em síntese, A incorporação da montmorilonita em diferentes proporções produziu diferentes morfologias, com boa eficiência de encapsulação e perfil adequado para a liberação controlada do fármaco.
\end{abstract}

Palavras-chave: Nanocompósitos; Ibuprofeno; Liberação controlada de fármacos.

\title{
Resumen
}

Se prepararon películas de nanocompuestos de quitosano / montmorillonita mediante el método de evaporación de solventes para inmovilizar el fármaco ibuprofeno (IBU) y retrasar su liberación en un medio que simula el ambiente del tracto gastrointestinal. Se estudiaron los efectos de la montmorillonita, en diferentes proporciones de masa (10, 20 y 50\%), sobre las propiedades morfológicas y físicas de las películas. Las muestras se caracterizaron por difracción de rayos X (DRX), espectroscopia infrarroja, microscopía electrónica de barrido, grado de hinchamiento, encapsulación del fármaco y eficacia de liberación del fármaco. Según la DRX se evidenció que la incorporación de montmorillonita al quitosano condujo a la formación de nanocompuestos de morfología ordenada. Los espectros infrarrojos confirmaron la buena interacción entre montmorillonita y quitosano mediante la formación de nanocompuestos. Este hecho, que favoreció el encarcelamiento de la IBU, redujo el coeficiente de difusión en los sistemas estudiados. Las micrografías comprobaron la formación de películas densas y uniformes. El perfil de liberación controlada, especialmente para el nanocompuesto con $10 \%$ de masa de arcilla, mostró una tasa de liberación de fármaco lenta. La incorporación de montmorillonita en diferentes proporciones produjo diferentes morfologías, con buena eficiencia de encapsulación y un perfil adecuado para la liberación controlada del fármaco.

Palabras clave: Nanocomposites; Ibuprofeno; Liberación controlada de fármacos.

\section{Introduction}

Clay-polymer nanocomposites have been being subject of study of multiple areas of knowledge. In particular, these hybrids show interesting biomedical properties while produced with biopolymers, such as chitosan, associated with layered silicates (clay minerals) (Barbosa et al., 2018). Clay-biopolymer nanocomposites are a novel class of versatile materials with an expanding range of possible applications involving drug delivery systems and tissue engineering (Mukhopadhyay et al., 2020).

Due to their cation exchange capacity and adsorptive potential, mineral clays can interact with drug molecules, facilitating their liberation. Sustained release of drugs, controlled by desorption from clay mineral excipients, was found favorable in the case of antibiotics, amphetamines, and anti-inflammatory drugs (Dziadkowiec et al., 2017). The montmorillonite (MMT) exhibits mucoadhesion and the capability to cross the gastrointestinal (GI) barrier, and adsorb bacterial and metabolic toxins such as steroidal metabolites. In particular, ibuprofen (IBU), which is cationic in nature, can also facilitate drug loading into interlayer regions of MMT and help to achieve adequate sustained-release (Manzoor et al., 2018).

Among the biopolymers, chitosan, a cationic polysaccharide consisting of D-glucosamine and $\mathrm{N}$-acetyl glucosamine units, has been extensively applied in drug delivery systems because it is biodegradable, biocompatible, nontoxic, nonimmunogenic, noncarcinogenic, antibacterial, and mucoadhesive properties. In addition, this polymer not only protects the drug molecules from degradation by proteolytic enzymes and prolongs the half-life time of the drug but also improves the drug bioavailability in vivo (Vukajlovic et al., 2019). The ability of chitosan to form films may permit its extensive use in the formulation of film dosage forms or as drug delivery systems. Biopolymers become adsorbed and intercalated in the interlayer 
space of smectite clay minerals, driven by electrostatic interactions. As a result, clay minerals may undergo delamination leading eventually to exfoliation. In such materials, clay mineral layers act as a nanometer-sized phase domain associated with a polymeric matrix. Such a unique structure may induce the modulated release of the drug due to the interaction with both the polymer and the clay mineral (Vieira et al., 2017).

In therapeutic applications, the efficiency of a drug lies in targeting specific body parts and maintaining the desired concentration level for a longer period. The IBU, a non-steroidal drug, an anti-inflammatory with analgesic and antipyretic properties, has its use is limited due to side effects, which are often consequences of high plasma levels following the administration of conventional formulations, due to the gastrointestinal toxicity 8. Additionally, IBU has an adverse systemic effect on gastric, mucosal protective agents. Another problematic issue is related to the fast absorption of the drug (maximum blood concentration levels of IBU are reached within 1-2 h) and its rapid elimination from the plasma ( $2 \mathrm{~h})$. Due to these disadvantages modified drug delivery systems for IBU are desired. Such systems should exhibit sustained release of the drug to: decrease dosing frequency, prevent reaching a toxic concentration of drug in the body, hinder unsteady release, and minimize the occurrence of side effects. Several authors report modified IBU delivery systems, based on differents matrixes (dos Santos et al., 2018).

By designing controlled delivery systems the desired concentration of drug can be maintained without reaching a higher toxic level or dropping below the minimum effective level 5. For this purpose, the interaction between the drug, biopolymer, and the lamellar host has been considered. In the present study we investigate the effect of nanohybrids chitosan/montmorillonite on physical properties, such as the microstructures, swelling behavior, and drug IBU release.

\section{Methodology}

Chitosan (CS) with a deacetylation degree of $92 \%$ was obtained from Polymar (Fortaleza, Brazil). Natural montmorillonite (MMT) was provided by Southern Clay Products Inc. (Gonzales, TX, USA) with a cation exchange capacity (CEC), given by the supplier, of $92.6 \mathrm{meq} / 100 \mathrm{~g}$. This compound was used without any further purification. Ibuprofen (IBU), with a molecular formula $\mathrm{C}_{13} \mathrm{H}_{18} \mathrm{O}_{2}$ and a molecular weight of $206.28 \mathrm{~g} / \mathrm{mol}$ (purity $\geq 98 \%$ ), was acquired from Sigma Aldrich (São Paulo, Brazil) and used as received. Sodium hydroxide, glacial acetic acid, hydrochloric acid and phosphate buffer solution (PBS) were supplied by Sigma Aldrich (São Paulo, Brazil). Ethyl alcohol (purity 99.8\%) was obtained from Neon Commercial (São Paulo, Brazil). All aqueous solutions were prepared using distilled water.

The production of films of the biomaterials developed in this work was proposed in order to study the mechanism of drug delivery in the skin (as dressings) and the gastric path (ingested in capsule format). Solution casting method was used to prepare CS films according to Darder et al. (2003) with some modification. In brief, chitosan (1\% w/v) was dissolved in $1 \%$ (v/v) acetic acid and stirred magnetically at $45^{\circ} \mathrm{C}$ for about $2 \mathrm{~h}$ until complete dissolution of chitosan. After complete dissolution, the solution was filtered through a Whatman filter paper (with pore diameter of $14 \mu \mathrm{m}$ ) to remove any undissolved material. A fixed amount of the resulting solution $(30 \mathrm{ml})$ was poured onto Teflon Petri plates $(10 \mathrm{~cm}$ diameter) to obtain a uniform polymer film. The plates were stored at room temperature $\left(\sim 23^{\circ} \mathrm{C}\right)$ for 5 days until complete evaporation of the solvent. After complete drying, the chitosan films were neutralized by $1 \mathrm{M} \mathrm{NaOH}$ for $30 \mathrm{~min}$. Then the neutralized films were washed several times with distilled water to wash off the alkali solution. Finally, these chitosan films were dried at room temperature for about 3 days in a pressed condition to make them wrinkle-free.

According to the same methodology, films of CS/MMT were prepared. The MMT suspension was prepared by dispersing appropriate amount of MMT into $100 \mathrm{ml}$ of distilled water. Chitosan solution, prepared as described above, had the $\mathrm{pH}$ adjusted to 4.9 with $\mathrm{NaOH}$ solution $(0.1 \mathrm{M})$. Afterwards, the chitosan solution was slowly added to the MMT suspension at $50^{\circ} \mathrm{C} \pm 2^{\circ} \mathrm{C}$ under continuous stirring (500 rpm) in appropriate amount to reach a final MMT concentration of 10, 20 and 50 
wt\% (based on chitosan weight). The CS/MMT mixtures were further stirred at $1200 \mathrm{rpm}$ for more $4 \mathrm{~h} \mathrm{at} 50^{\circ} \mathrm{C} \pm 2^{\circ} \mathrm{C}$. Subsequently, the mixtures were filtered through a Whatman filter paper (with pore diameter of $14 \mu \mathrm{m}$ ) and then casted onto Teflon Petri dishes $(10 \mathrm{~cm}$ diameter). The castings were dried and neutralized like described in section above. The films prepared with 10, 20 and $50 \mathrm{wt} \%$ of MMT were labeled as CS/10MMTf, CS/20MMTf and CS/50MMTf, respectively.

The procedure used to form the CSf and CS/MMTf loaded with IBU model drug was similar to the protocol described above. IBU powder (10\% w/w based on the chitosan) was dissolved in ethyl alcohol $(10 \mathrm{mg} / \mathrm{ml})$. Next, the prepared solution was added drop by drop to CS solution and CS/MMT mixtures, homogenized under magnetic stirring for 24 hours at room temperature, filtered to remove the excess of unloaded drug and poured into Teflon Petri dishes (10 cm diameter). Finally, all mixtures formed films after drying at room temperature for $\sim 5$ days. The formed films were neutralized, washed and dried using the mentioned procedure in section 2.2. The resulting materials were referred as CS/IBUf, CS/10MMT/IBUf, CS/20MMT/IBUf and CS/50MMT/IBUf.

All samples were characterized by X-Ray diffraction, Fourier-Transform Infrared Spectroscopy, Scanning Electron Microscopy, Swelling Degree, Drug loading and Encapsulation Efficiency, and in vitro Drug Release. The XRD patterns of all samples were obtained using a Shimadzu diffractometer model XRD-7000, equipped with Ni-filtered $\mathrm{Cu}-\mathrm{K} \alpha$ radiation $(\lambda=$ $0.15418 \mathrm{~nm}$ ) at room temperature. The XRD spectrums were collected in a scattering range of $2 \theta$ from $2^{\circ}$ to $12^{\circ}$ with resolution of $0.02^{\circ}$ at a scanning speed of $2 \% \mathrm{~min}$. The analyses were made by applying an accelerating voltage of $40 \mathrm{kV}$ and current intensity of $30 \mathrm{~mA}$. The d-spacing $\left(\mathrm{d}_{001}\right)$ was calculated by Bragg's formula:

$$
d_{001}=\frac{\lambda}{2 \sin \theta}
$$

Structural characterization of the prepared samples was recorded on a FTIR spectrometer (Bruker, Vertex 70 spectrophotometer) using ATR (attenuated total reflection) mode of operation. All spectra were collected with wavenumber ranging from 4000 to $400 \mathrm{~cm}^{-1}$ during 64 scans, with $4 \mathrm{~cm}^{-1}$ resolution.

The surface morphology of prepared films was analyzed using scanning electron microscopy (SEM, Tescan-model Vega 3). Samples were mounted on aluminum stubs with double-sided carbon adhesive dots, sputter coated with gold, and observed by SEM. Images were taken by applying an electron beam accelerating voltage of $15 \mathrm{kV}$.

The swelling degree of the CSf and CS/MMTf was investigated in phosphate buffered saline (PBS) at various time intervals. The films $(1 \mathrm{~cm} \mathrm{x} 1 \mathrm{~cm})$ dried at $50^{\circ} \mathrm{C}$ for $24 \mathrm{~h}$ were weighed initially (Mdry) and immersed in PBS (pH 7.4) at $37^{\circ} \mathrm{C}$. At predetermined intervals (15, 30, 60, 120 and 180 minutes), swollen samples were taken out and blotted off carefully in between tissue papers (without pressing hard) to remove the surface-adhered liquid droplets and then weighed (Mwet). Five replicates were performed on each sample. The swelling degree (SD) was calculated using the Equation 2. To determine the significance of differences among samples, analysis of variance (ANOVA) was used. Minitab® 19 statistical software was employed to perform the analysis and Tukey's test was utilized for multiple comparisons. Significance of differences was defined at $\mathrm{p}<0.05$.

$$
S D(\%)=\frac{W_{d r y}-W_{\text {Wet }}}{W_{\text {dry }}} \times 100
$$

Where $\mathrm{w}_{\text {dry }}$ means the dry weight of the samples, and $\mathrm{w}_{\text {wet }}$ means the wett weight of the samples.

Samples of drug-loading films were cut into four parts, accurately weighed, and put into glass vessels containing 10 $\mathrm{ml}$ of PBS (pH 1.2), as illustrated in Figure 1. The samples were maintained at $37^{\circ} \mathrm{C}$ until complete dissolution $(48 \mathrm{~min})$. 
Subsequently, the solution $(10 \mathrm{ml})$ was transferred to dialysis bag (cellulose dialysis membranes, with MCWO 12,000 14,000). Prior to dialysis bag is filled with the solution, it was immersed in distilled water for $2 \mathrm{~h}$ to remove any preservatives, rinsed thoroughly with water and immersed in the PBS pH 1.2 to equilibrate for $1 \mathrm{~h}$ according to the protocol described by Dziadkowiec et al. (2017). The bag, sealed with plastic clips, was shaken and immediately immersed in the $150 \mathrm{ml}$ of the release medium (PBS pH 1.2), which was sonicated using a constant pulse program for 48 minutes. Aliquots of 3 ml were withdrawn at fixed time interval (48 min until $100 \mathrm{~h}$ ) and after the concentration of IBU was measured by UV-Vis Spectroscopy in triplicates, using a spectrophotometer (Perkin Elmer, Lambda 35) and a quartz cuvette at $\lambda_{\max }=222 \mathrm{~nm}$, it was returned to released medium. The error was expressed as a standard deviation. The estimation of drug percentage loading and the encapsulation efficiency were obtained using Equations 3 and 4 (Ambrogi et al., 2018):

$$
\begin{aligned}
& \% \text { drug loading }=\frac{\text { mass of drug in film }(\mathrm{mg})}{\text { mass of the film }(\mathrm{mg})} \times 100 \\
& \% \text { encapsulation efficiency }=\frac{\text { drug loading }}{\text { total mass of drug added (theorefical loading) }} \times 100
\end{aligned}
$$

Figure 1. Sample of drug-loading film (a); cut of the films (b) and drug-loading film parts immersed in PBS (c).

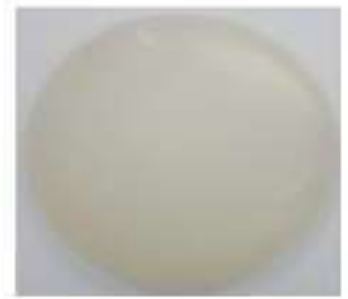

(a)

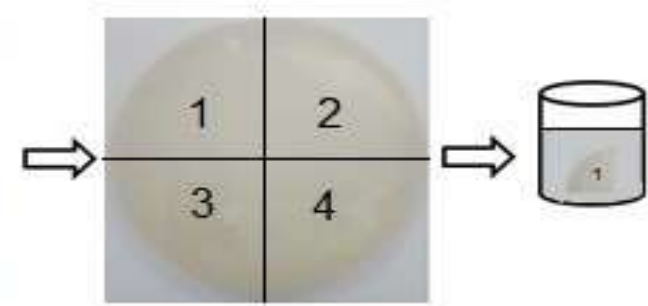

(b)
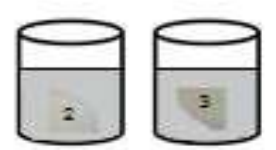

(c)

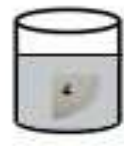

Source: Authors.

In vitro ibuprofen release measurements were conducted by UV-Vis spectroscopy (Perkin Elmer, Lambda 35) using dialysis technique. More specifically, drug-loading CS and CS/MMT films were cut into four parts, accurately weighed, and put into a pre-hydrated cellulose membrane containing $10 \mathrm{ml}$ of PBS at different pHs (1.2 and 7.4). After that the dialysis bag were sealed with plastic clips and placed at the bottom of dissolution vessels containing $150 \mathrm{ml}$ of $\mathrm{PBS}$ ( $\mathrm{pH} 1.2$ and $\mathrm{pH} 7.4$ ), in order to simulated gastric fluid and blood $\mathrm{pH}$, respectively. The systems were sonicated at the physiological temperature of $37^{\circ} \mathrm{C} \pm 0.5{ }^{\circ} \mathrm{C}$ for 48 minutes, and afterward were maintained at the same temperature under continuous shaking conditions $(150 \mathrm{rpm})$ in an incubator shaker (IKA-KS4000i). Finally, aliquots of $3 \mathrm{ml}$ were withdrawn at predetermined time intervals up to $100 \mathrm{~h}$ and the concentration of IBU was measured by UV-Vis spectroscopy at $\lambda_{\max }=222 \mathrm{~nm}$. After each measurement, the withdrawn was put back into the system. Prior to characterizing the drug release quantitatively, the calibration curves of IBU in PBS solutions at the two pHs were established. Blank CSf and CS/MMTf without drug was used as the control. The experiments were performed in triplicate to minimize the error variation. Average values were used for further data treatment and plotting. The drug concentration was calculated according to a standard curve, and accumulative release was obtained by the following equation:

$$
\text { Cumulative release }(\%)=\frac{\sum_{i}^{n} C_{i} V_{0}}{w} \times 100
$$


Where $\mathrm{V}_{0}$ is the volume of the sample $(3 \mathrm{ml}), \mathrm{Ci}$ is the concentration $(\mathrm{mg} / \mathrm{l})$ of release drug collected at time, and $\mathrm{w}$ is the mass of the drug containing sample $(\mathrm{mg})$.

\section{Results and Discussion}

Figure 2 shows the XRD patterns of ibuprofen (IBU), montmorillonite (MMT), chitosan films (CSf), chitosan/ibuprofen films (CS/IBUf), chitosan/ montmorillonite films with 50, 20 and $10 \%$ by mass of (CS/50MMTf, CS/20MMTf and CS/10MMTf) and with the incorporation of ibuprofen (CS/50MMT/IBUf, CS/20MMT/IBUf and CS/10MMT/IBUf), confirming the formation of nanocomposites.

Figure 2. RXD profiles of MMT, IBU, and CS, CS/MMT films before and after the IBU loading.

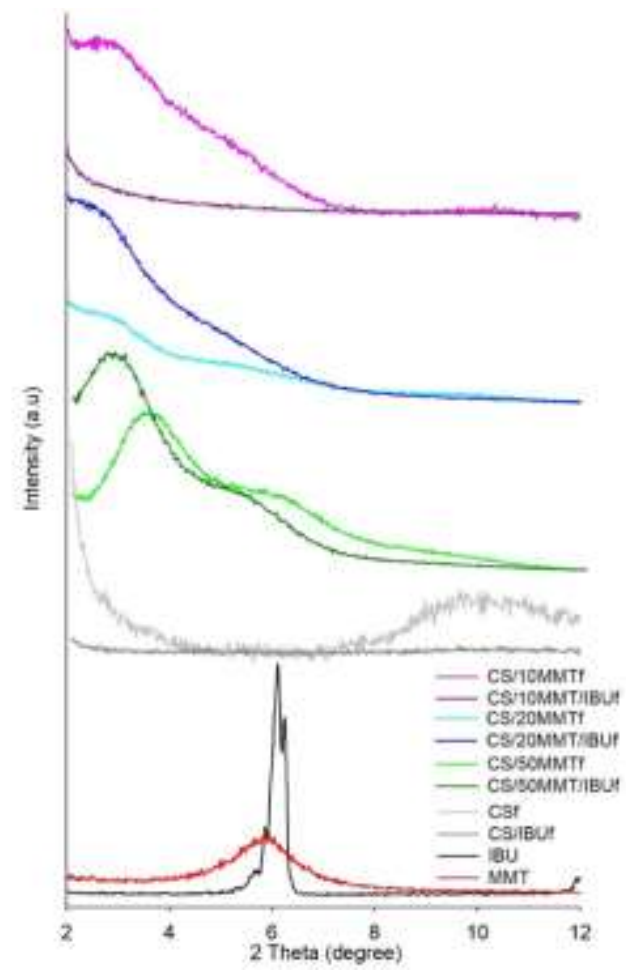

Source: Authors.

The montmorillonite diffractogram presented a reflection peak (001) at approximately $6.0^{\circ}$, corresponding to a basal interplanar distance $\left(\mathrm{d}_{001}\right)$ of $1.47 \mathrm{~nm}$, characteristic of montmorillonite sodium (Paiva, Morales \& Díaz, 2008). In the diffractogram of the chitosan (CSf), a broad band of low intensity between 8-12 , typical of semi-crystalline material was observed, corroborating with the diffractograms presented in other studies (Luo et al., 2017; Baskar \& Kumar, 2009). As described by Ogawa et al. (1992), shows the characteristic crystalline peaks around $2 \theta=10$, corresponds to the crystalline form of the chitosan structure and presents a unit cell with $\mathrm{a}=7.76 \AA$, $\mathrm{b}=10.91 \AA \mathrm{c}=10.30 \AA$ and $\beta=90^{\circ}$ which is related to the diffraction plane (100). Pure ibuprofen exhibits typical reflection at $2 \theta=6.06^{\circ}$, the same value found by (Zheng et al., 2007). In the diffractogram of the CS/IBUf sample did not observe the characteristic reflections of the biopolymer and the drug, suggesting the dispersion of the IBU, at molecular level in the chitosan matrix (Hua et al., 2010).

The baseline spacings of the CS/50MMTf, CS/20MMTf and CS/10MMTf samples were $2.61 \mathrm{~nm}\left(2 \theta=3.38^{\circ}\right), 2.94 \mathrm{~nm}$ $\left(2 \theta=3.01^{\circ}\right)$ and $2.98 \mathrm{~nm}\left(2 \theta=2.96^{\circ}\right)$, respectively. Considering the thickness of the montmorillonite layer of $0.96 \mathrm{~nm}$, the GAPs between the layers were $1.65 \mathrm{~nm}, 1.98 \mathrm{~nm}$, and $2.02 \mathrm{~nm}$, respectively. According to Tan et al. (2008), it is possible that a bilayer of chitosan molecules has been intercalated between the layers of montmorillonite clay, since values referring to a basal 
interplanar distance $\left(\mathrm{d}_{001}\right)$ around $2.02 \mathrm{~nm}$ indicate that chitosan bilayers were positioned between the montmorillonite layers. This interaction was possibly favored by the electrostatic interaction of the second layer (-NH3+) with the acetate ions of the chitosan solution, which allowed the access to the sites for anion Exchange (Choi et al., 2016; Tan et al., 2008).

For the CS/50MMTf, CS/20MMTf and CS/10MMTf systems containing IBU (CS/50MMT/IBUf, CS/20MMT/IBUf and CS/10MMT/IBUf), the basal interplanar distance disappeared for the CS/10MMT/IBUf system, suggesting an exfoliated type morphology (Barbosa et al., 2009). For the CS/20MMT/IBUf system, a peak displacement of the clay was presented for values lower than $2 \theta\left(2 \theta=2.65^{\circ}\right)$, resulting in an increase in interlamellar distance $\left(\mathrm{d}_{001}=3.31 \mathrm{~nm}\right)$ suggesting a disordered intercalated morphology tending to exfoliation. In the CS/50MMT/IBUf system there was a peak around $2 \theta=2.76^{\circ}\left(\mathrm{d}_{001}=\right.$ $3.20 \mathrm{~nm}$ ), a value lower than that presented in the system without incorporation of the drug, indicating the formation of a nanocomposite of orderly intercalated morphology (Braga et al., 2012).

In general, all systems presented chitosan and IBU intercalation in the clay lamellae and the amount of clay mixed with chitosan affected the morphology of the nanocomposites obtained. For the nanocomposites formed, the reflection around $6.06^{\circ}$ characteristic of the IBU crystals disappeared. Hua et al. (2010) attributed this behavior to the dispersion of the drug, at the molecular level in the chitosan matrix, or to the intercalation of the same between the layers of the clay.

FTIR spectroscopy analysis was performed to characterize the presence of specific chemical groups and possible interactions between CS, MMT and IBU in the films and to analyze any chemical structural changes in films obtained after drug loading.

In Figure 3a, all samples presented a spectrum band in the region of 3460-3280 $\mathrm{cm}^{-1}$ that was attributed to $\mathrm{OH}$ and $\mathrm{NH}$ stretching vibrations. Discrete bands were observed around 2914 and $2817 \mathrm{~cm}^{-1}$ attributed to the asymmetric and symmetrical axial stretch of the $\mathrm{C}-\mathrm{H}$ bond of the $-\mathrm{CH}_{2}$ and $-\mathrm{CH}_{3}$ groups (Martino et al., 2017). Peaks observed around $1630 \mathrm{~cm}^{-1}$ were assigned to $\mathrm{C}=\mathrm{C}$ stretching of the secondary amide (Marchessault, Ravenelle \&. Zhu, 2006). In the region of $1420-1270 \mathrm{~cm}^{-1}$ that was attributed to the symmetrical angular deformation of the - $\mathrm{CH} 3$ group, indicating the presence of acetamide groups, since the chitosan is not totally deacetylated (Kolhe \&. Kannan, 2003). In the region of $1135-1026 \mathrm{~cm}^{-1}$ that was attributed to $\mathrm{C}-\mathrm{O}$ in the $\mathrm{COH}, \mathrm{COC}$ and $\mathrm{CH} 2 \mathrm{OH}$ ring (Mincheva et al., 2004). From Figure 3a, it was concluded that films QCL50, QCL20 and QCL10 observed bands aroud $1580 \mathrm{~cm}^{-1}$ corresponding to the vibrational deformation of the protonated amine group ($\mathrm{NH} 3+$ ), indicating the possible interaction between chitosan and clay (Silva et al., 2013). The infrarred spectrum in Figure $3 \mathrm{~b}$ all samples showed a strong carbonyl absorption band at $1621 \mathrm{~cm}^{-1}$ and the bands between 3500 and $3100 \mathrm{~cm}^{-1}$ are related to the aromatic ring of ibuprofen. The bands between 3000 and $2800 \mathrm{~cm}^{-1}$ are the alkyl stretching vibration of ibuprofen. 
Figure 3. FTIR spectra of CS and CS/MMT films before (a) and after IBU loading (b).
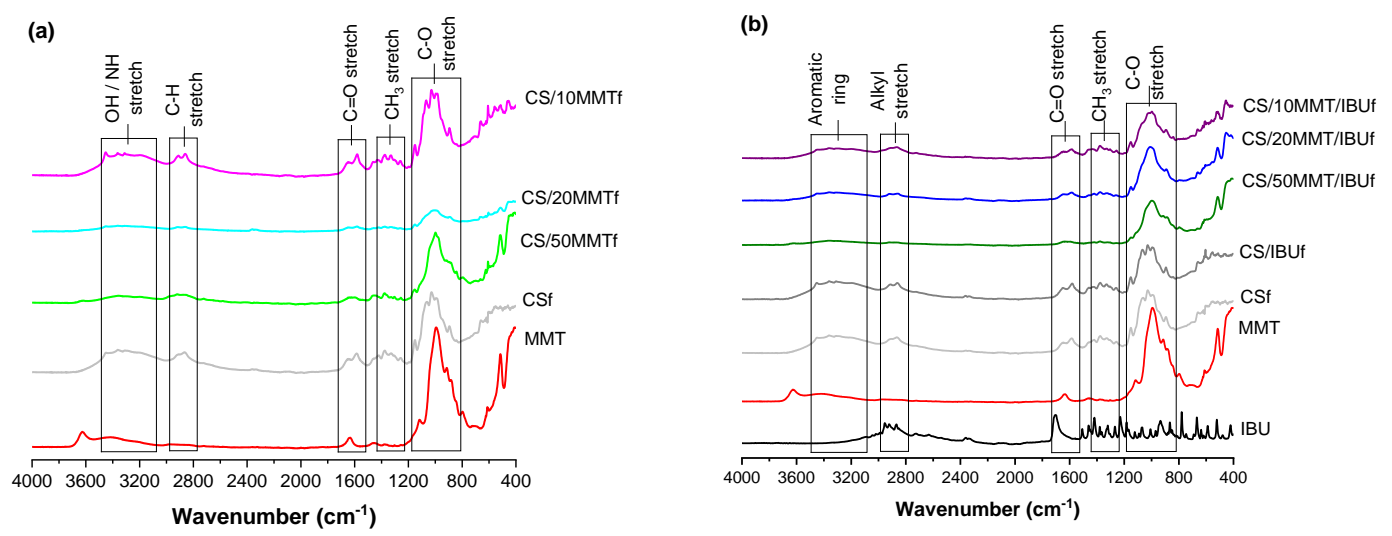

Source: Authors.

Figure 4 shows the Scanning Electron Micrographs of the films before and after drug loading and also after in vitro IBU release at different magnifications. The micrograph of the chitosan (CS) film presented, in some areas, a uniform, smooth and flat surface, characterizing the film as dense (Marreco et al., 2004). The micrographs of the chitosan/montmorillonite films in the different mass concentrations of montmorillonite (CS/50MMTf, CS/20MMTf and CS/10MMTf) showed the presence of small but well distributed clusters. According to a study carried out by (Wang et al., 2005), the formation of agglomerates in chitosan/montmorillonite systems is a result of the edge-edge interactions of the hydroxyl groups present in the octahedral layers of montmorillonite. In general, the films loaded with ibuprofen had a good interaction between the components, with the formation of compact films and with good surface dispersion, but it was still possible to verify in some systems the presence of some agglomerates. In the present study, the use of ibuprofen in the treatment of the disease was not associated with the presence or absence of the drug. Regarding the films after being submitted to the in vitro test, the presence of voids/pores can be attributed to the removal of the crystals of ibuprofen, emphasizing the purpose of the research that would be the release of the drug when subjected to conditions that mimic the processes absorption by the human body.

Figure 4. SEM photomicrographs from the top surface of CS and CS/MMT films before IBU loading, after IBU loading and in vitro IBU release microstructure.
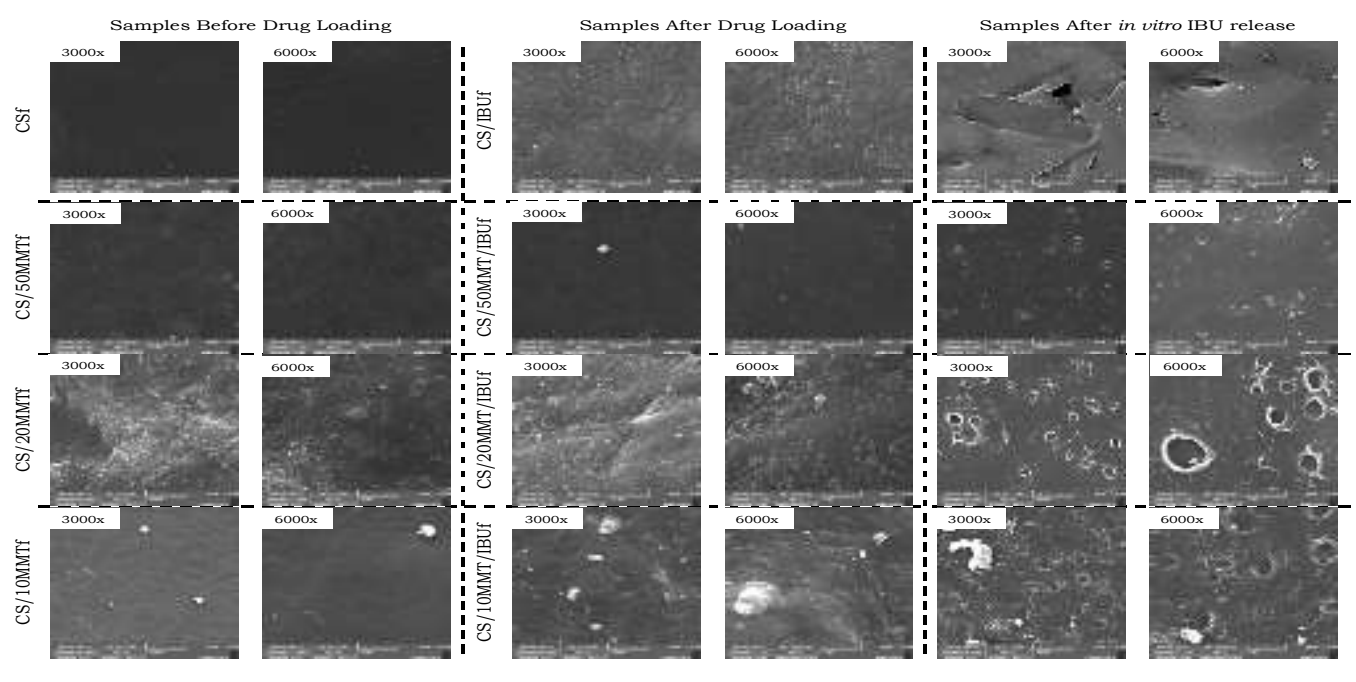

Source: Authors. 
The degree of swelling of the films of chitosan (CSf), chitosan/IBU (CS/IBUf), chitosan/montmorillonite with 50, 20 and $10 \%$ by mass of clay (CS/50MMTf, CS/20MMTf and CS/10MMTf) and chitosan/montmorillonite with an incorporation of the drug (CS/50MMT/IBUf, CS/20MMT/IBUf and CS/10MMT/IBUf) are present in Table 1. This test was performed only at $\mathrm{pH} 7.4$, since at $\mathrm{pH} 1.2$ it would not be possible, due to the solubilization of chitosan.

Table 1. Degree of Swelling of the films.

\begin{tabular}{lccccc}
\hline Samples & $\mathbf{t}=\mathbf{1 5} \mathbf{~ m i n}$ & $\mathbf{t}=\mathbf{3 0} \mathbf{~ m i n}$ & $\mathbf{t}=\mathbf{1}$ hora & $\mathbf{t}=\mathbf{2}$ horas & $\mathbf{t}=\mathbf{3}$ horas \\
\hline CSf & $75 \pm 1,2 \mathrm{~A}$ & $70 \pm 0,6 \mathrm{~A}$ & $72 \pm 0,5 \mathrm{AB}$ & $50 \pm 0,3 \mathrm{AB}$ & $92 \pm 0,9 \mathrm{AB}$ \\
CSIBUf & $79 \pm 0,6 \mathrm{~A}$ & $99 \pm 1,0 \mathrm{AB}$ & $85 \pm 0,3 \mathrm{AB}$ & $68 \pm 1,3 \mathrm{AB}$ & $100 \pm 0,7 \mathrm{AB}$ \\
CS/50MMTf & $47 \pm 0,3 \mathrm{~A}$ & $45 \pm 0,7 \mathrm{~A}$ & $51 \pm 0,1 \mathrm{~A}$ & $56 \pm 0,9 \mathrm{AB}$ & $82 \pm 0,3 \mathrm{~A}$ \\
CS/50MMT/IBUf & $51 \pm 0,2 \mathrm{~A}$ & $52 \pm 0,1 \mathrm{~A}$ & $50 \pm 0,6 \mathrm{~A}$ & $30 \pm 0,2 \mathrm{~A}$ & $49 \pm 0,3 \mathrm{~A}$ \\
CS/20MMTf & $61 \pm 1,4 \mathrm{~A}$ & $75 \pm 0,3 \mathrm{~A}$ & $62 \pm 1,3 \mathrm{AB}$ & $89 \pm 0,1 \mathrm{BC}$ & $93 \pm 0,4 \mathrm{AB}$ \\
CS/20MMT/IBUf & $52 \pm 0,7 \mathrm{~A}$ & $171 \pm 1,4 \mathrm{~B}$ & $129 \pm 1,1 \mathrm{~B}$ & $99 \pm 0,5 \mathrm{BC}$ & $154 \pm 0,7 \mathrm{~B}$ \\
CS/10MMTf & $75 \pm 0,8 \mathrm{~A}$ & $62 \pm 0,5 \mathrm{~A}$ & $94 \pm 0,8 \mathrm{AB}$ & $126 \pm 0,7 \mathrm{C}$ & $110 \pm 0,6 \mathrm{AB}$ \\
CS/10MMT/IBUf & $64 \pm 0,1 \mathrm{~A}$ & $65 \pm 0,2 \mathrm{~A}$ & $69 \pm 0,4 \mathrm{AB}$ & $54 \pm 0,8 \mathrm{AB}$ & $47 \pm 0,2 \mathrm{~A}$ \\
\hline
\end{tabular}

A-C: Different superscript lowercase letters within the same row indicate significant differences by the Tukey test (p $<0.05)$. Source: Authors.

According to the statistical swelling data shown above it was possible to affirm that in the initial time of the swelling test $(\mathrm{t}=15 \mathrm{~min})$ there was no significant influence of the variables (clay and drug). In the second time analyzed $(\mathrm{t}=30 \mathrm{~min})$, the CS/20MMT/IBUf showed greater absorption of PBS. In the fourth time studied (t = 2 hours), CS/20MMTf, CS/20MMT/IBUf and CS/10MMTf exhibited a main value of swelling. We suggest the CS/20MMT/IBUf system as a strong candidate in the swelling drug release process, since its hydrophilic matrix absorb fluids while releasing the drug from the polymeric surface, forming a gelatinous layer of polymer (malleable state). As the phosphate buffer solution - PBS hydrates the dry core, a gelled outer layer can be eroded by partial or total solubilization of the polymer (physical erosion). The penetration of a certain fluid causes the polymer chains to move apart, promoting the diffusion of the drug (Lopes et al., 2005; Masood, 2007).

According to the results showed in Table 2 displayed below, the drug loading in the films varied between 4.11 to $7.30 \%$ and the encapsulation efficiency varied approximately between 53 and $87 \%$ for the films carried with the drug, corroborating the results obtained by Lamprachet et al. (2004) and Dziadkowiec et al. (2017), who used ibuprofen encapsulated in lipid nanocapsules and in montmorillonite nanomposites with guar gum, and respectively, and different from an encapsulation range between 16 to $90 \%$. It was also observed that the lowest encapsulation efficiency was presented by the CSIBUf system, indicating that an incorporation of clay into the systems favors an encapsulation of the drug. The presence of clay in the films increased the encapsulation efficiency of the IBU, especially in those with 50 and $10 \%$ by mass of clay. According to Azhar and Olad (2014), a preparation of nanocomposites of this type (drug + clay) can expand the interlayer space, leading to greater intercalation of the drug into the system. For the CS/20MMT/IBUf system, the encapsulation efficiency was much lower, in relation to the others, however in the SEM, we observed the presence of more voids, as if the IBU had left almost entirely in the film, a fact probably associated with the nature of the test, as this was done only on the surface of the obtained films. 
Table 2. Values of drug loading and drug loading efficiency of the films prepared.

\begin{tabular}{ccc}
\hline Samples & $\begin{array}{c}\text { Drug Loading } \\
(\mathbf{w t .} \%)\end{array}$ & $\begin{array}{c}\text { Encapsulation efficiency } \\
(\mathbf{w t . \%})\end{array}$ \\
\hline CS/IBUf & 4,93 & 53,50 \\
CS/50MMT/IBUf & 4,11 & 86,32 \\
CS/20MMT/IBUf & 4,50 & 58,58 \\
CS/10MMT/IBUf & 7,30 & 87,60 \\
\hline
\end{tabular}

Source: Authors.

In vitro drug release was studied under PBS (pH 1.2 and 7.4), and release media was quantified by UV-vis spectral absorbance values. Figure 5 shows the release (\%) of Ibuprofen versus immersion time from both film.

Figure 5. Ibuprofen release profile from the prepared samples in PBS pH 1.2 and 7.4.
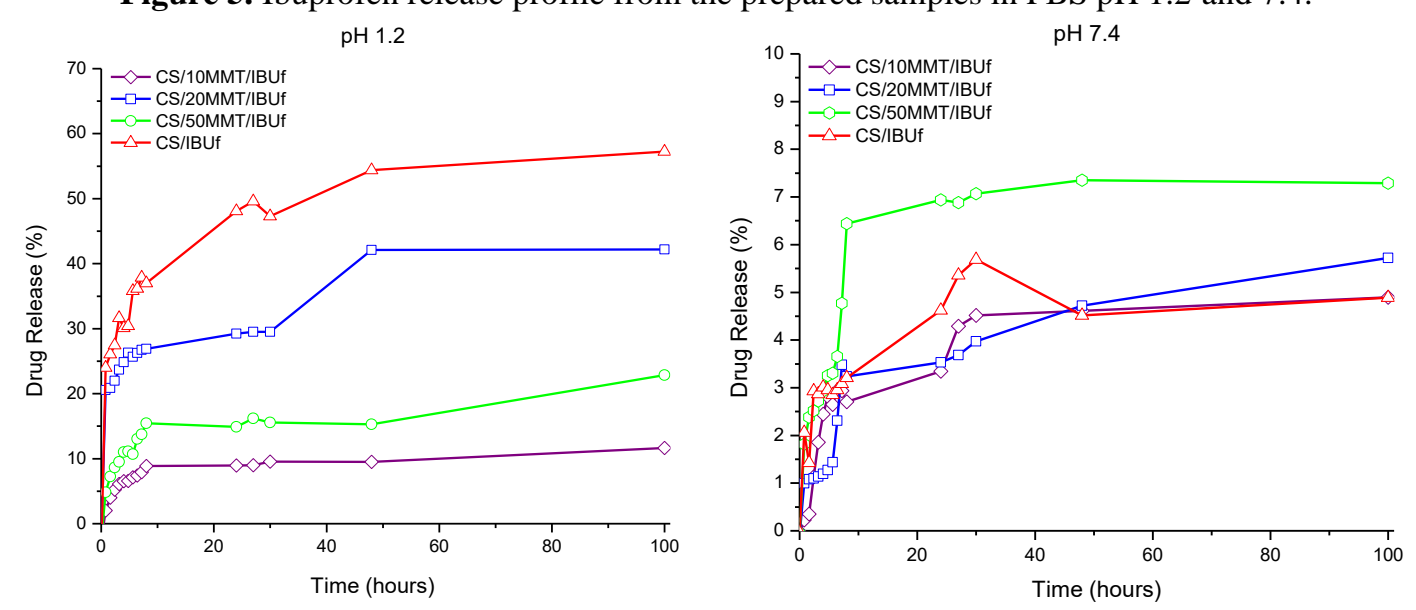

Source: Authors.

The release profiles at $\mathrm{pH} 7.4$ were different from the release profiles release at $\mathrm{pH} 1.2$ for all films studied. It was observed that there was a slower release (lower slope of the release curve) in the first hours in relation to the sudden release that occurred at $\mathrm{pH}$ 1.2. This fact may be related to the dissolution of chitosan in an acidic environment, in the presence of acidic $\mathrm{pH}$. It is also suggested that when the compound is homogeneously dispersed in the polymeric chitosan matrix, the release of the drug may include processes of water penetration in the matrix, promoting swelling, the diffusion of the compound through the pores/voids and, finally, the erosion of the polymer. After 100 hours, the maximum mass (mg), concentration $(\mu \mathrm{g} / \mathrm{mL})$ and IBU released $(\%)$ at $\mathrm{pH} 1.2$ and 7.4 in the systems are listed in the Table 3.

Table 3. Values the maximum mass, concentration and IBU released at $\mathrm{pH} 1.2$ and 7.4 in the systems.

\begin{tabular}{|c|c|c|c|c|c|c|}
\hline \multirow[b]{2}{*}{ Samples } & \multicolumn{3}{|c|}{ pH 1.2} & \multicolumn{3}{|c|}{ pH 7.4} \\
\hline & $\begin{array}{l}\text { Mass } \\
(\mathbf{m g})\end{array}$ & $\begin{array}{c}\text { Concentration } \\
(\mu \mathrm{g} / \mathrm{mL})\end{array}$ & $\begin{array}{c}\text { Drug released } \\
(\%)\end{array}$ & $\begin{array}{l}\text { Mass } \\
(\mathrm{mg})\end{array}$ & $\begin{array}{c}\text { Concentration } \\
(\mu \mathrm{g} / \mathrm{mL})\end{array}$ & $\begin{array}{c}\text { Drug released } \\
(\%)\end{array}$ \\
\hline CS/IBUf & 5.29 & 30.00 & 43.00 & 0.64 & 3.00 & 4.30 \\
\hline CS/50MMT/IBUf & 3.74 & 20.00 & 17.67 & 1.33 & 8.00 & 6.02 \\
\hline CS/20MMT/IBUf & 7.32 & 50.00 & 39.16 & 0.97 & 6.00 & 5.16 \\
\hline CS/10MMT/IBUf & 1.81 & 10.00 & 10.07 & 0.75 & 4.00 & 4.20 \\
\hline
\end{tabular}

Source: Authors. 
The release kinetics of the IBU of the films was evaluated using the model de Korsmeyer et al. (1983). The exponent values found for the IBU release profiles in $\mathrm{pH} 1.2$ and 7.4 are shown in Table 4. The value of ' $\mathrm{n}$ ' indicated that they have suffered influence of the montmorillonite content used in the systems and that in PBS pH 1.2 and 7.4 the release of the IBU from the films the CS/IBUf, CS/50MMT/IBUf, CS/20MMT/IBUf and CS/10MMT/IBUf occurred by a Fick diffusion mechanism ( $\mathrm{n}<0.5$ ), corroborating with the results presented by Tang et al. (2014). They concluded that the rapid swelling and erosion of the chitosan films had little effect on the drug release. It is worth mentioning that the value of $\mathrm{b}$ is negative for all profiles of release in PBS pH 1.2 and 7.4, in the mathematical model proposed by Korsmeyer Peppas. However, theoretically, the value of b, which represents the rapid release of drug ("burst effect"), must be a positive value. When releasing IBU in PBS $\mathrm{pH} 1.2$, these negative values may have been caused by the use of the dialysis that restricted the rapid diffusion of drug molecules from the internal environment to the external, according to the result presented by Tan et al. (2014). You can still attribute this effect by the release of the drug on the surface of the system matrix or by changes in the system structure with consequent release immediate drug followed by slower release.

Table 4. Regression parameters of the Korsmeyer equation in the drug release in the films CS/IBUf, CS/50MMT/IBUf, CS/20MMT/IBUf and CS/10MMT/IBUf in PBS pH 1.2 and 7.4.

\begin{tabular}{|c|c|c|c|c|c|c|c|c|}
\hline \multirow{2}{*}{ Amostra } & \multirow[b]{2}{*}{$\mathbf{K}$} & \multicolumn{3}{|c|}{ pH 1.2} & \multicolumn{4}{|c|}{ pH 7.4 } \\
\hline & & $\mathbf{n}$ & b & $\mathbf{R}^{2}$ & $\mathbf{K}$ & $\mathbf{n}$ & b & $\mathbf{R}^{2}$ \\
\hline CS/IBUf & 0,1199 & 0,1758 & 0,0816 & 0,9853 & 0,0759 & 0,2050 & 0,0312 & 0,8531 \\
\hline CS/50MMT/IBUf & 0,0937 & 0,1895 & 0,1219 & 0,9285 & 0,0479 & 0,2556 & 0,0668 & 0,8631 \\
\hline CS/20MMT/IBUf & 0,1504 & 0,1492 & 0,0522 & 0,9431 & 0,0126 & 0,3493 & 0,0516 & 0,9013 \\
\hline CS/10MMT/IBUf & 0,1771 & 0,1548 & 0,2532 & 0,9382 & 0,0380 & 0,2730 & 0,0948 & 0,8610 \\
\hline
\end{tabular}

Source: Authors.

\section{Conclusion}

Obtaining chitosan/montmorillonite nanocomposite films, in mass proportions of 10,20, and 50\% clay, using the solvent evaporation method, showed reproducible results to immobilize the ibuprofen drug (IBU) and delay its release when subjected to an environment that simulates the gastrointestinal tract. During the obtaining of the membranes, ibuprofen was lost in the washing step, interfering in the IBU encapsulation efficiency and, consequently, in the capacity of loading the drug through the systems.

According to the results of X-ray diffraction it was evidenced that the incorporation of montmorillonite to chitosan led to the formation of nanocomposites of ordered morphology, tending to exfoliation in CS/50MMT/IBUf, CS/20MMT/IBUf, and CS/10MMT/IBUf. Through the photomicrographs obtained by the Sscanning Electron Microscopy was verified the formation of dense films and the probable formation of voids in its structure by drug's liberation from the system. The infrared spectra confirmed the good interaction between montmorillonite and chitosan by the formation of nanocomposites. This fact, which favored the imprisonment of the IBU, reduced the diffusion coefficient in the studied systems. The mathematical model for release from films, obtained from Fick's diffusion laws, had good representation in PBS medium pH 1.2 and 7.4, with typical behavior of Fick. The nanocomposites showed a controlled release profile, especially the chitosan /montmorillonite/IBU nanocomposite with 10\% clay mass (CS/10MMT/IBUf), which reproduced a slower drug release rate. 
The methodology used was considered adequate for the synthesis of chitosan/montmorillonite nanocomposite films with high encapsulation efficiency and with controlled drug release characteristics, indicating that these films can be considered promising systems for administering IBU, causing fewer adverse reactions when administered orally.

\section{References}

Abdeen, R. \& Salahuddin, N. (2013). Modified Chitosan-Clay Nanocomposite as a Drug Delivery System Intercalation and In Vitro Release of Ibuprofen. Journal of Chemistry, 1, 1-9.

Ambrogi, V., Perioli, L., Ricci, M., Pulcini, L., Nocchetti, M., Giovagnoli S. \& Rossi, C. (2018). Eudragit ${ }^{\circledR}$ and hydrotalcite-like anionic clay composite system for diclofenac colonic delivery. Microporous and Mesoporous Materials. 115 (3), 405-412.

Azhar, F. F. \& Olad, A. (2014). A study on sustained release formulations for oral delivery of 5-fluorouracil based on alginate-chitosan/montmorillonite nanocomposite systems. Applied Clay Science, 101, 288-296.

Barbosa, H. D. C., Santos, B. F. F., Tavares, A. A., Barbosa, R. C., Fook, M. V. L., Canedo, E. L. \& Silva, S. M. L. (2018). Inexpensive apparatus for fabricating microspheres for 5-fluorouracil controlled release systems. International Journal of Chemical Engineering, 2018, 1-8.

Baskar, D. \& Kumar, T. S. S. (2009). Effect of deacetylation time on the preparation, properties and swelling behavior of chitosan films. Carbohydrate Polymers, 78 (4), 767-772.

Braga, C. R. C., Barbosa, R. C., Lima, R. S. C., Fook, M. V. L. \& Silva, S. M. L. (2012, July). Nanocompósitos Quitosana/Montmorilonita para Aplicação em Liberação Controlada de Fármacos. Poster presented at the 10th Congresso Brasileiro de Polímeros, Maringá, PR.

Choi, C., Nam, J. P. \& Nah, J. W. (2016). Application of chitosan and chitosan derivatives as biomaterials. Journal of Industrial and Engineering Chemistry, $33,1-10$.

Darder, M., Colilla, M. \& Ruiz-Hitzky, E. (2003). Biopolymer-clay nanocomposites based on chitosan intercalated in montmorillonite. Chemistry of Materials, 15 (20), 3774-3480.

Dziadkowiec, J., Mansa, R., Quintela, A., Rocha, F. \& Detellier, C. (2017). Preparation, characterization and application in controlled release of Ibuprofenloaded Guar Gum/Montmorillonite Bionanocomposites. Applied Clay Science, 135, 52-63.

Hua, S., Yang, H., Wang, W. \& Wang, A. (2010). Controlled release of ofloxacin from chitosan-montmorillonite hydrogel. Applied Clay Science, 50 (1), 112117.

Kolhe, P. \& Kannan, R. M. Improvement in ductility of chitosan through blending and copolymerization with PEG: FTIR investigation of molecular interactions. Biomacromolecules, 4 (1), 173-180.

Korsmeyer, R. W., Gurny, R., Doelker, E., Buri, P. \& Peppas, N. A. (1983). Mechanisms of solute release from porous hydrophilic polymers. International Journal of Pharmaceutics, 15 (1), 25-35.

Lopes, C. M., Lobo, J. M. S. \& Costa, P. (2005). Formas farmacêuticas de liberação modificada: polímeros hidrifílicos. Revista Brasileira de Ciências Farmacêuticas, 41 (2), 143-154.

Luo, D., Sang, L., Wang, X., Xu, S. \& Li, X. (2011). Low temperature, pH-triggered synthesis of collagen-chitosan-hydroxyapatite nanocomposites as potential bone grafting substitutes. Materials Letters,65 (15), 2395-2397.

Masood, S. (2007). Application of fused deposition modelling in controlled drug delivery devices. Assembly automation, 27 (3), $215-221$.

Manzoor, K., Ahmad, S., Soundarajan, A., Ikram, S. \& Ahmed, S. (2018). Chitosan Based Nanomaterials for Biomedical Applications. Handbook of Nanomaterials for Industrial Applications, 543-562.

Marchessault, R. H., Ravenelle, F. \& Zhu, X. X. (2006). Polysaccharides for drug delivery and pharmaceutical applications. ACS Publications, Washington.

Marreco, P. R., Moreira, P. L., Genari, S. C. \& Moraes, A. M. (2004). Effects of different sterilization methods on the morphology, mechanical properties, and cytotoxicity of chitosan membranes used as wound dressings. Journal of Biomedical Materials Research - Part B, 71 (2), 268-277.

Martino, A., Kucharczyk, P., Capakova, Z., Humpolicek, P. \& Sedlarik, V. (2017). Chitosan-based nanocomplexes for simultaneous loading, burst reduction and controlled release of doxorubicin and 5-fluorouracil. International Journal of Biological Macromolecules, 102, 613-624.

Mincheva, R., Manolova, N., Sabov, R., Kjurkchiev, G \& Rashkov, I. (2004). Hydrogels from chitosan crosslinked with poly (ethylene glycol) diacid as bone regeneration materials. e-Polymers, 4 (1), 1-5.

Mukhopadhyay, R., Bhaduri, D., Sarkar, B., Rusmin, R., Hou, D., Khanam, R., Sarkar, S., Biswas, J. K., Vithanage, M. \& Bhatnagar, A. (2020). Claypolymer nanocomposites: Progress and challenges for use in sustainable water treatment. Journal of Hazardous Materials, 383, 121125.

Paiva, L., Morales, A. \& Díaz, F. (2008). Argilas organofílicas: características, metodologias de preparação, compostos de intercalação e técnicas de caracterização. Cerâmica, 54 (330), 213-226.

Santos, B. F. F., Maciel, M. A., Tavares, A. A., Fernandes, C. Q. B. A., Sousa, W. J. B, Fook, M. V. L., Leite, I. F. \& Silva, S. M. L. (2018). Synthesis and preparation of chitosan/clay microspheres: Effect of process parameters and clay type. Materials, 11 (12), 2523. 
Research, Society and Development, v. 11, n. 1, e25911124684, 2022

(CC BY 4.0) | ISSN 2525-3409 | DOI: http://dx.doi.org/10.33448/rsd-v11i1.24684

Silva, S. M., Braga, C. R., Fook, M. V. L., Raposo, C. M., Carvalho, L. H. \& Canedo, E. L. (2012). Application of infrared spectroscopy to analysis of chitosan/clay nanocomposites. Infrared Spectroscopy - Materials Science, Engineering and Technology.

Tan, W., Zhang, Y., Szeto, Y. \& Liao, L. (2008). A novel method to prepare chitosan/montmorillonite nanocomposites in the presence of hydroxy-aluminum oligomeric cátions. Composites Science and Technology, 68 (14), 2917-2921.

Vieira, A. P., Badshah, S. \& Airoldi, C. (2013). Ibuprofen-loaded chitosan and chemically modified chitosans-release features from tablet and film forms. International Journal of Biological Macromolecules, 52, 107-115.

Vukajlovic, D., Parker, J., Bretcanu, O. \& Novakovic, K. (2019). Chitosan based polymer/bioglass composites for tissue engineering applications. Materials Science and Engineering: C, 96, 955-967.

Wang, S., Shen, L., Tong, Y., Chen, L., Phang, I., Lim, P. \& Liu, T. (2005). Biopolymer chitosan/montmorillonite nanocomposites: preparation and characterization. Polymer Degradation and Stability, 90 (1), 123-131.

Zheng, J., Luan, L., Wang, H., Xi, L. \& Yao, K. (2007). Study on ibuprofen/montmorillonite intercalation composites as drug release system. Applied Clay Science, 36 (4), 297-301. 